\title{
Role of industrial cooperation and inter-cluster interaction in the development of localization of production in shipbuilding
}

\author{
Alexey Serbulov, and Marina Shaliapina* \\ Immanuel Kant Baltic Federal University, Gorkogo str., 23, 236000, Kaliningrad, Russia
}

\begin{abstract}
An effective tool that allows you to dampen economic losses from the Western sanctions imposed on our country is the development of international cooperation and the associated processes of localization of production. However, along with the positive effect, there are a number of administrative and organizational problems that impede the expected results from both foreign partners and domestic manufacturers. On the example of the shipbuilding industry, the problems of further development of inter-cluster interaction are shown both at the national and international levels. It is shown how participation in the formation of the Panel of Equipment Suppliers, which is an extensive computer system for managing procurement activities and material and technical supply of shipyards, will expand the opportunities for foreign companies to participate in the implementation of large-scale government orders.
\end{abstract}

\section{Introduction}

The complexity of the current foreign policy situation in which Russia finds itself requires an urgent solution to the most urgent task facing the country's economy, formulated as "import substitution and expanding the range of the products".

Given the fact that our economy is still attractive for foreign direct investment, the state economic policy pays serious attention to the development of local production, considering it as a way to solve the above problem.

The Government of the Russian Federation creates a legal environment favorable for investors, counting on the creation with their help of competitive industries in strategically important industries for the country, which will lead to a decrease in Russia's dependence on imported products [1].

Federal Law No. 488-Ф3 dated December 31, 2014 "On Industrial Policy in the Russian Federation" provides for a system of state support measures aimed at the formation of a competitive industry corresponding to the innovative type of development of the domestic economy. Following the aforementioned law, a number of regulations have been adopted regarding the localization of industry, taking into account: a specific industry; specifics of financing an investment project (in the case of using public funds); the specifics of the process of selling the finished products, if the buyer is the state or the

* Corresponding author: m-shaliapina@mail.ru 
companies with the state participation, or implementation in the $\mathrm{B} 2 \mathrm{~B}$ market is envisaged.

In recent years, domestic practice has accumulated significant experience in the creation of innovative industrial clusters by well-known foreign companies together with Russian manufacturers [2; 3]. Of course, the leaders in this matter are German, Chinese, Korean and Japanese automakers. But there are positive examples in other sectors of the economy. For example, in the Lipetsk region, with the active participation of one of the largest manufacturers of household appliances in Europe, the Italian machine-building company Indesit Company (bought by the American Whirlpool Corporation in 2014), an innovative territorial cluster of complex household appliances (refrigerators, freezers, washing machines) was created. Today the cluster cooperates with more than 250 foreign suppliers of spare parts. Therefore, the prospects for the development of the anchor enterprise JSC "Indesit International" are associated with the localization of production within the national territory.

In partnership with the Lazio Regional Health Cluster (Italy), C.H.I.CO. (Cluster of Health, Innovation and Community) a pharmaceutical cluster has been created in the Kaluga region, the main task of which is to conduct preclinical and clinical research, development, synthesis and introduction into production of pharmaceutical substances and radiopharmaceuticals, industrial production of finished medicines and pharmaceutical substances. Today it can be stated that $70 \%$ of the products manufactured by the enterprises of this domestic cluster are innovative.

However, the presence of a number of specific problems arising in the process of cluster development: growing competition within the cluster, lack of resources for the implementation of certain projects, etc. forces clusters to look for new ways to grow.

For example, the organization of inter-cluster interaction, and at the highest level, which makes it possible to successfully combine the interests of all parties (participants in an integrated structure, regions, industries, the state).

Developing a system of inter-cluster interaction, clusters support entrepreneurship within their competence, based on the principles of business cooperation, which favorably affects the activities of all participants and allows them to predict steady economic growth [4].

The past decade has been characterized by the development of international industrial cooperation processes. To further build the potential of economic instruments for ensuring national competitiveness, localization of industrial production within its own territory is necessary. Localization allows solving a number of problems that arise at the present stage of the economic development of society as a whole and its productive forces. Among them are the following:

1. Preservation of the country's economic sovereignty.

2. Overcoming export and import restrictions.

3. Unification of Russian requirements and approaches to localization in accordance with existing international practice.

4. Development of our own productive forces through the development of advanced technology and technological practice, acquisition of new personnel competencies, activation of the resource and energy factor, etc.

A partner company that locates production on Russian territory also pursues certain goals that do not contradict the goals of the Russian participants, the host region and the state as a whole. Among them, improving market positions through guaranteed sales of products in Russia and the member states of the Eurasian Economic Union (EAEU), reducing costs due to the cheapness of labor, geographical proximity to sources of raw materials and energy resources, reducing the adverse impact on the ecosystem of their country. 
Let's consider the localization of production within the framework of inter-cluster interaction using the example of shipbuilding clusters.

Shipbuilding is one of the leading sectors of the economy with high scientific, technical and production potential, influencing the development of technologies in related industries.

The existing production capacities and resources of the Russian shipbuilding industry allow increasing the volume of civil and defense products.

According to some estimate given in [5], the shipbuilding industry includes about 600 enterprises, including 180 shipyards, more than 90 design and research organizations, 310 enterprises that produce ship components for various purposes, the cost of which depending on the type of ships and samples of marine equipment, can be more than $50 \%$.

To increase the competitiveness of the industry, the Government of the Russian Federation created a number of preferences for both export-oriented industries and the domestic market, aimed at increasing the motivation for locating and expanding production in Russia (Table 1).

Table 1. Measures of state support in the shipbuilding industry implemented by the Ministry of Industry and Trade of Russia, contributing to the effective promotion of the policy of import

substitution and localization

\begin{tabular}{|c|c|c|c|c|c|}
\hline \multirow{2}{*}{$\begin{array}{l}\text { Measures to support the shipbuilding } \\
\text { industry }\end{array}$} & \multicolumn{4}{|c|}{ Budget allocations, mld. Rub. } & \multirow{2}{*}{$\begin{array}{l}\text { Number of } \\
\text { subsidized } \\
\text { vessels, units }\end{array}$} \\
\hline & 2020 & 2021 & 2022 & 2023 & \\
\hline $\begin{array}{l}\text { Subsidies for reimbursement of part of } \\
\text { the cost of interest on loans for the } \\
\text { purchase of civil ships and lease } \\
\text { payments under lease agreements }\end{array}$ & 3.8 & 3.8 & 3.8 & - & 120 \\
\hline $\begin{array}{l}\text { Ship recycling grant (Resolution of the } \\
\text { Government of the Russian Federation } \\
\text { No. } 502 \text { dated April 27, 2017) }\end{array}$ & 0.5 & 0.5 & 0.5 & - & 10 \\
\hline $\begin{array}{l}\text { Leasing program for sea and river civil } \\
\text { vessels }\end{array}$ & - & \multicolumn{3}{|c|}{$\begin{array}{l}\text { The Ministry of Industry and } \\
\text { Trade of Russia plans to } \\
\text { prepare an application for } \\
\text { additional financing in the } \\
\text { amount of } 105 \text { billion rubles. }\end{array}$} & 82 \\
\hline $\begin{array}{l}\text { Encouraging the construction of small } \\
\text { and medium-sized fishing vessels at } \\
\text { domestic shipyards (within the } \\
\text { framework of the decree of the } \\
\text { government of the Russian Federation } \\
\text { No. } 1917 \text { dated December 27, 2019) }\end{array}$ & 0.393 & 0.360 & 0.360 & - & - \\
\hline $\begin{array}{l}\text { Granting subsidies from the federal } \\
\text { budget to Russian organizations to } \\
\text { financially support part of the costs } \\
\text { associated with the construction of } \\
\text { large-tonnage vessels (within the } \\
\text { framework of the RF government } \\
\text { decree No. } 1584 \text { dated December } 4 \text {, } \\
2019 \text { ) }\end{array}$ & 4.915 & 7.2 & 9.9 & - & 18 \\
\hline
\end{tabular}

*Compiled by the authors from the source [6]

At the level of the Government of the Russian Federation, such measures are considered to stimulate the entry of foreign companies into a joint business on terms of localization, such as the possibility of VAT refunds upon subsequent re-export of products. In addition, upon signing a special investment contract (SPIC), a foreign investor can claim to simplify the administrative procedures for the development of its activities, obtain the status of a Russian manufacturer, and, therefore, access to government contracts. 
Shipbuilding and ship repair enterprises have a rather pronounced specificity in the organization of production and economic activities.

Firstly, this production is highly specialized, which affects the nature of the resources used.

Secondly, it is a high-tech production with a high level of application of innovative technologies. In shipbuilding, 3D modeling, specialized software for cutting, cutting and processing workpieces with $\mathrm{CNC}$ machines, and robotic welding are widely used. Fireproof aluminized coatings are more and more actively used, which guarantee corrosion resistance and significantly reduce the cycle of painting.

And, finally, thirdly, this is a geographically concentrated production, which is concentrated in large maritime centers with direct access to sea areas (Arkhangelsk, Astrakhan, Kaliningrad, Murmansk, St. Petersburg) and having a long-standing shipbuilding tradition.

The above key characteristics make it possible to classify the shipbuilding industry as a strategically important sector of the economy, which implies that it is under the unconditional care of the state.

However, it is precisely this development strategy that has led to the fact that almost all the leading enterprises of Russian shipbuilding and ship repair today are concentrated as part of a state-monopoly structure - United Shipbuilding Company JSC (USC) with 100\% of shares backed by federal ownership. This industrial giant has an annual production turnover of over 300 billion rubles and a number of employees of over 90 thousand people at enterprises located in various regions of the country.

The main share of the use of the resources of the USC enterprises is associated with the fulfillment of state orders, namely, orders for the construction of ships for the Navy, marine equipment for the development of the Arctic shelf and orders for foreign trade cooperation. All of the above are the federal projects.

However, lately there have been more and more opinions [7] that the desire for excessive centralization forms a number of negative characteristics of the economic environment. In particular, internal competition in the industry is eliminated, the quality of management decreases, and interagency barriers are created.

An example of this is the conflict of interests of shipbuilding and ship repair enterprises, which are simultaneously part of the USC and the composition of the ubiquitous industrial shipbuilding clusters. And it is connected with the fact that, in parallel with the state order at the sectoral and regional level, a stable interest of investors has formed in the implementation of commercial projects related to the renewal and modernization of the fleet. In particular, this is due to an increase in demand for fishing vessels, cruise passenger ships, ferries, pleasure yachts, as well as vessels of the research fleet.

The complexity of the current foreign policy situation in which Russia finds itself requires the prompt solution of the most urgent problem facing the shipbuilding industry, formulated as "import substitution and expanding the range of products" [8].

However, the high price, low quality, problems associated with repair and maintenance have led to the low competitiveness of domestic products, which results in a large share of the cost of this type of foreign-made product in the structure of the cost of ship component equipment (for civil shipbuilding - up to $85 \%$, for military - up to $60 \%$ ) [9].

The current situation explains the significant dependence of the domestic shipbuilding industry on foreign supplies, which, along with the sanctions policy of the individual states, the global economic crisis entailing fluctuations in exchange rates, poses a threat to the entire industry, creating the risks of increasing costs and disruption of construction time, and in some cases, endangering the very possibility of building certain types of products in Russia. 
Since the formation and development of intersectoral clusters in Russia is declared as one of the most important directions of the industrial development strategy (for the period up to 2035), the cluster approach can be considered as a new round of localization of both foreign and Russian companies in the regions of the Russian Federation, within which the formation of pool of domestic suppliers around an enterprise with foreign investment [10].

\section{Materials and methods}

The study of the processes of localization of production in industry is based on the study of data from sectoral statistical reporting provided by the Ministry of Industry and Trade of the Russian Federation, data from official statistics bodies. A significant amount of information for further analysis is contained in regulatory documents (Federal laws, resolutions of the Government of the Russian Federation, local regulations). In particular, the decrees of the Government of the Russian Federation on the program of import substitution in the shipbuilding industry in 2015 and 2019 are of great practical value for understanding the strategy of state influence on the processes of import substitution.

In the process of studying this issue, the materials of scientific reviews of the European Cluster Observatory "Cluster Collaboration and Business Support Tools to Facilitate Entrepreneurship, Crosssectoral Collaboration and Growth" (2014), the working group on shipbuilding of the Secretariat of the Organization for Economic Cooperation and Development "Shipbuilding Market Developments" (2018).

When conducting the research, the authors used general logical methods of the theoretical level (analysis, synthesis, generalization, analogy), as well as the empirical level (observation, description, comparison).

\section{Results and discussion}

The use of production localization within the framework of inter-cluster interaction with the help of a pool of domestic and foreign manufacturers of spare parts, raw materials, equipment, directly contributes to import substitution, as well as ensuring a complete production chain within the cluster.

Based on the materials of the study of the processes of interaction of shipbuilding clusters in the North-West region [4], 6 enlarged groups of resources were identified that are used in the implementation of large inter-cluster projects and require resource interaction between its participants.

The economic characteristics of each resource can be presented as follows (Table 2).

Table 2. Characteristics of the resource potential in the field of inter-cluster interaction

\begin{tabular}{|l|l|}
\hline \multicolumn{1}{|c|}{ Resource potential type } & \multicolumn{1}{|c|}{ Resource potential characteristics } \\
\hline Human resources & $\begin{array}{l}\text { Demonstrates the provision of industry enterprises with } \\
\text { basic production assets and production infrastructure. }\end{array}$ \\
\hline Innovation potential & $\begin{array}{l}\text { It is a set of demographic and social characteristics of } \\
\text { the economically active population working at industry } \\
\text { enterprises in the region. }\end{array}$ \\
\hline Investment potential & $\begin{array}{l}\text { It is characterized by a set of all types of resources and } \\
\text { conditions for the creation and practical development of } \\
\text { the results of scientific research and development. }\end{array}$ \\
\hline Determined by the volume of investments aimed at \\
modernizing and developing the industry in the region.
\end{tabular}


Table 2. Continued

\begin{tabular}{|l|l|}
\hline Financial potential & $\begin{array}{l}\text { It is a collection of financial resources that can be } \\
\text { attracted for the implementation of inter-cluster projects. }\end{array}$ \\
\hline Information potential & $\begin{array}{l}\text { It is represented by a set of information resources that } \\
\text { provide connections between the participants in inter- } \\
\text { cluster interaction. }\end{array}$ \\
\hline
\end{tabular}

The owners of all the listed resources are the business entities. However, the decision to transfer these resources on a reimbursable basis to other participants in cluster projects is made by a specially created structure - the Inter-Cluster Interaction Control Center (ICICC), which acts as a coordinator providing the process of interaction between clusters based on the information management platform, one of the functions of which is to optimize the procurement activities. [11]

It should be noted that the principle of retribution for various types of resource potential is implemented in different ways. In this sense, it is possible to divide the resources transferred within the framework of the inter-cluster exchange to be returned into the following groups:

1. Resources completely consumed in the process of use (raw materials, materials, quickly worn out tools, equipment, intellectual property, etc.). They are returned not in material, but in monetary form in full amount of their commercial value.

2. Resources returned with a loss of value (immovable production facilities, equipment, etc.). Returned in tangible form with payment of the cost of depreciation and the commercial benefit of the resource owner.

3. Resources returned without loss of production capabilities with payment of the cost of use (remuneration of workers of other enterprises seconded to carry out work on the implementation of inter-cluster projects).

4. Irrevocably transferable resources with full payment of the cost or on the principles of mutually beneficial exchange (information, design and technological documentation, intellectual creations, etc.).

In the process of designing and building a ship, a three-way interaction is formed customers, manufacturing plants, equipment suppliers, where each of the parties has its own interests. To harmonize the interests of all the participants in shipbuilding projects, a regulatory framework is needed that regulates the relationship between the parties, which would determine interaction with resource suppliers, relations within the corporation, as well as between partners within the framework of inter-cluster interaction.

Such a platform for managing MTS processes in long, constantly repetitive business processes is the "Panel of suppliers in civil shipbuilding", which is a management system for procurement activities and material and technical supply of shipyards of the United Shipbuilding Corporation group of companies. Developed since 2017, this system is designed to ensure the formation and constant updating of an array of information about the suppliers and the nomenclature of their products in an automated mode.

The modern practice of material and technical support within the framework of the activities of state corporations suggests that there should not be only one supplier for any item of equipment [12]. This is prohibited by Russian competition law.

\section{Conclusions}

Inclusion in the shipbuilding clusters of the "pilot pool of suppliers" localized on the territory of the cluster in such areas as: main mechanisms ("Wartsila", "MAN", "Yanmar", "Schottel", "Steerprop", "ABB"); marine equipment ("Fluidmecanica", "Vulkan Nova", "Adria Winch"); ship navigation equipment ("Furuno", "Polar", "OSK Technologies"); 
equipment for cargo ("Liebherr", "Sormec", "Palfinger", "Gurdesan"), as well as the attraction of clusters from related industries (machine tools, metallurgy, etc.), will provide the full production cycle with the necessary resources, and therefore will provide an opportunity to localize the production of equipment and component parts most in demand in shipbuilding.

For the timely provision of the processes with the necessary equipment, components, tooling, etc., it is necessary to provide for a pre-order period for negotiations with the customers. This provision is especially important when organizing and carrying out ship repair and emergency operations, where the possibilities of preliminary planning and ordering of equipment necessary for replacement or restoration are very limited.

Following the classification of the resources proposed by us above, the suppliers of the first and, partially, the second group of the resources will be included in the developed "Supplier Panel". At the same time, not only the requirements for the product should be formed, but also the requirements for the supplier in terms of ensuring the delivery time, the quality of equipment and its service.

To develop the processes of inter-cluster interaction and create conditions for the localization of production, it will be advisable to create a distributed database (DDB) of equipment suppliers in all existing and newly created territorial clusters of shipbuilding and ship repair.

The inclusion of the potential partners in the Supplier Panel will stimulate not only domestic, but also foreign manufacturers to fulfill the government's requirements for expanding localization in the shipbuilding industry.

\section{References}

1. V. A. Tsvetkov, M. N. Dudin, A. A. Yurieva, Economy of Region, 691 (2020)

2. A. Andrésen, E. Laaksonen, H. Mäkinen, Smart Comp Research Report (2012)

3. Laaksonen, E. Mäkinen, H. Journal of East-West Business, 95 (2013)

4. M.A. Shalyapina, Kazan. econom. bulletin, 618 (2018)

5. V. Khanichev, D. Stoyanov, Sh. Petrosyan, Business magazine Neftegaz.RU, 23 (2019)

6. N. Valuisky, S. Vinarova, G. Yegorov, PortNews IAA, 3 (2020)

7. V.N. Zazimko, Expert Union, 12 (2019)

8. A.M. Butov, Shipbuilding products market 2018, 125 (2018)

9. Strategy for the development of the shipbuilding industry for the period up to 2035 No. 2553-p dated October 28, 2019 ConsultantPlus (2019)

10. O.P. Ivanova, The region's economy, 1215 (2018)

11. M.A. Shalyapina, Actual problems of economic development and management: collection of scientific papers, 425 (2018)

12. V.S. Ismagilova, A.R. Ismagilova, Economic management: methods, models, technologies: proceedings of the XIX International scientific conference, 157 (2019) 